Sławomir Buryła

\title{
Manly Fascism
}

DOI: 10.18318/td.2017.en.2.8

Yes! Yes! Yes! Humanitarian war exists only in anaemic minds. Here, Eva, in our magical hideout, in the Berghof, everything seems beautiful, pleasant, as if enchanted. And I seem different: a calm, ordinary person. But it is an illusion: I have never been, and never will be such a person, much as I would like to be... ${ }^{1}$

Could one not find a better portrait of the torturer in the history of Polish literature than this one, from a novel by a (justly) forgotten author? Without doubt. More than one. I choose Andrzej Rodan's Ostatnie dni Sodomy [The Last Days of Sodom], however, to point to popular literature as a significant cognitive context. During the communist era, members of the SS and Gestapo or Wehrmacht soldiers often appeared in typical genres of popular culture, a trend that has only increased following the economic and political transformation. This is a topic for a separate study. For now, it suffices to mention that in contemporary media-civilisation, and as a result also in the public consciousness, we encounter at least two vibrant models
Sławomir Buryła

- Professor at the Institute of Polish

Philology at the University of Warmia and Mazury, Head of the Department of Literary Theory. His interests include the literature of war and occupation, editing, and popular culture and literature. Among his recent publications is Tematy (nie)opisane [(Un)described Themes]. Contact: slawomirburyla@ wp.pl

1 Andrzej Rodan, Ostatnie dni Sodomy (Warszawa: Polwar, 1988), 148. If not otherwise specified all translations of referenced works are provided by the translator of the article. 
of manliness: the gangster and the Nazi. The former is mostly constituted by the cinema (from the classic examples of the 1940s, '50s and ' 60 s to the latest works), while the latter is constructed by works of literature and films as well as the earlier clichés and widespread social ideas; these are based on stereotypes of German neatness and resourcefulness, upon which is built a vision of a handsome, elegant man - an art lover and at the same time a ruthless murderer.

Pop culture particularly absorbed one element of the image of the Nazi - the SS officer as a symbol of masculine sexual potency. Much of the pornographic production in the 1970 s and ' 80 s was made under the banner of fascism. Here we must mention the genre of "Nazi exploitation," which was especially popular at the time. The action in such films usually took place in concentration camps, Gestapo prisons and brothels for German soldiers. The tormenters they depicted were often women. Ilse Koch, the wife of the Buchenwald commandant, carved out a remarkable career. The film version of her became a symbol of the hidden desires of the twentieth-century consumer of pop culture - the dreams of emancipated sexuality. ${ }^{2}$ These go hand in hand with pan-sexualism and postmodernity's well-known attention to sexual matters. The Nazi style (black uniforms, whips, swastikas, leather boots and belts) inevitably seems to connote erotic subtexts. Atrocities and masculine allure, exhibited and embodied in the accessories of violence and rape, come together here. In her essay Fascinating Fascism, Susan Sontag writes:

[...] boots, leather, chains, Iron Crosses on gleaming torsos, swastikas, have become, along with meat hooks and heavy motorcycles, the secret and most lucrative paraphernalia of eroticism. ${ }^{3}$

A further interesting cultural phenomenon is that of "stalags" - slim comics drawn and written by Israelis. These emerged in the newly formed Israeli state in the 1960s, shortly after the trial of Adolf Eichmann. Stylised to resemble the memoirs of survivors, at the time they were one of few sources of information on the Nazi camps. Yet it was not knowledge about the camps located in the territory of Poland, Germany and Central Europe that accounted for the high levels of sales of "stalags," but rather the abundance of erotic scenes. Shock at

2 See Marek Kaźmierczak, Auschwitz w Internecie. Przedstawienia Holokaustu w kulturze popularnej (Poznań: Wydawnictwo Naukowe UMK, 2012), 100.

3 Susan Sontag, "Fascinating Fascism," The New York Review of Books, February 6, 1975, http://www.nybooks.com/articles/1975/02/06/fascinating-fascism/, accessed December 20, 2017. 
the violence and pornographisation of the Holocaust led the Israeli government to ban the distribution of "stalags."

Among the manifold accessories of fascism, it was especially the uniform and swastika that evoked erotic associations, often crossing boundaries. ${ }^{5}$ Even more strongly than the images of the male slaughterers, it is the figures of female executioners who depict this transgressive nature of Nazism. Koch became the heroine of several dozen pornographic films (the best-known being Ilsa-She Wolf of the SS). Incidentally, from the point of view of the needs of the Nazi exploitation genre, a better candidate than Koch would be Irma Grese. Along with her youth - she was just 22 years old when she died - the Auschwitz guard combined beauty, brutality, and sexual insatiability. ${ }^{6}$ She therefore satisfied the essential conditions for inflaming male dreams and desires.

In the Nazi world, organised according to a patriarchal model, an erotic, exciting interplay of oppositions takes place, including male-female and sadistic-masochistic. ${ }^{7}$ The combination of sex and cultural taboo, which has accompanied the figure of the executioner for centuries, ${ }^{8}$ is extremely enticing for the "popular imagination." It was in this area of sexuality - apart from the social and political realms - that the domination of men in the Third Reich was manifested. It was shaped by "manly behaviours, making reference to potency and reproductive power." 9 In special institutions where "the children of the Führer" were to be born, women were fertilised by SS members. The

4 Joanna Czopowicz, Obrazy przemocy. Współczesne przedstawienia "ikon zagłady," http:// issuu.com/ planetar/docs/obrazyprzemocy, 138, accessed March 30, 2015.

5 On the sexualisation of fascism in film see, for example, Grzegorz Ojcewicz, "Seksualność faszyzmu," in Skazani na trwanie. Odmieńcy XX wieku w esejach Jarosława Mogutina (Olsztyn: Stowarzyszenie Artystyczno-Kulturalne "Portret," 2007). Piotr Krupiński offers an interesting discussion of this subject, taking into account the drama and prose of Marian Pankowski, in his essay "Eros i Auschwitz w twórczości Mariana Pankowskiego," in Ciało, historia, kultura. Pisarstwo Mariana Pankowskiego i Leo Lipskiego wobec tabu, ed. Piotr Krupiński (Szczecin: Wydawnictwo Naukowe US, 2011).

6 See Daniel Patrick Brown's monograph The Beautiful Beast: The Life \& Crimes of SS-Aufseherin Irma Grese (San Marino, CA: Golden West, 2004); as well as A. Vázquez-Figueroa, La Bella Bestia (Barcelona: Martinez Roca, 2012).

7 Krupiński, Ciało, historia, kultura, 106.

8 See Roger Caillois, "The Sociology of the Executioner," in The College of Sociology (1937-39), ed. Georges Bataille (Minneapolis: University of Minnesota Press, 1988).

9 Dorothee Schmitz-Köstner, W imię rasy. Dzieci dla Führera - mity i rzeczywistość, trans. R. Wojnakowski (Warszawa: Trio, 2000), 187. Original version: Deutsche Mutter, bist du bereit. Alltag im Lebensborn (Berlin: Aufbau Taschenbuch, 2010). 
secret of the future progeny was hidden in the male sperm, deriving from the best representatives of the Aryan race. Candidates for fatherhood were previously selected in terms of race. The man seemed to be the more important element in the process of forming the future life, for he provided not only the genetic material, but also the spirit of the Germanic hero. And this was seen as something much more significant than the offspring's outward bodily appearance. It also corresponds to the well-known distinction according to which masculinity is linked to logos, and femininity to corporeality. Summarising the ideas of Simone de Beauvoir, Judith Butler argues that:

[...] the universal person and the masculine gender are conflated, thereby defining women in terms of their sex and extolling men as the bearers of a body-transcendent universal personhood. ${ }^{\mathbf{1 0}}$

The vocation of SS members was to beget male children. In the future, it was they who were to strengthen the ranks of the army. In terms of their fundamental missions, the Lebensborn once again legitimised the domination of men over women. These institutions, established by Heinrich Himmler, were places where masculinity could reveal itself in all its beauty, achieving a remarkable level of self-admiration. Here, the sense of power given by service in the army, the police or any military or paramilitary units, was bolstered by state-approved extramarital sex. The number of conquests of women (as well as the number of children left behind) ennobled the men not only in their own eyes, but also in those of others. This did not happen without the participation of women. It was their gaze that was supposed to confirm to the SS warrior the importance of the power that Nazism attributed to the soldier's and policeman's uniform. The women from the Third Reich were laid - often with their consent - on the altar of German nationalism and militarism. A necessary supplement to these two ideologies was sexism.

Reflection on fascism reveals the process of the erotisation of reality in Hitler's totalitarian empire. Racial purity was celebrated, to be exhibited by nudity, athletic masculinity, and physical fitness. The characteristics that were thus cultivated in the public consciousness were therefore those attributed to men - biological strength, in which the advantage of the male over the female is expressed in wartime.

Fascism frequently manifested its ambivalent approach to human sexuality. Out for a stroll in 1930 s Berlin, Antoni Sobański sees hordes of pushy prostitutes. He cannot reconcile this fact with the moral puritanism espoused

10 Judith Butler, Gender Trouble: Feminism and the Subversion of Identity (New York: Routledge, 2006), 13. 
by the regime, which sometimes takes the guise of official prudery. But soon he reaches the simplest of possible conclusions - the regime seamlessly melds ideology with pragmatism. Perhaps this is even its primary characteristic, although one not discerned by the citizens of the totalitarian state. Yet the interlocutors that Sobański meets have no problem with calling a spade a spade. As they argue:
Although reproducing, and so marriage, is the ideal of National Social- ism, sexual intercourse as an extremely masculine act [author's emphasis] can be tolerated, as long as the man shows a woman who does not intend to become a mother the requisite contempt and brutality.11

The Third Reich always performed a balancing act between ideologically motivated nudity and sensuality with sexual subtexts. ${ }^{12}$ As Lech M. Nijakowski writes, "Pornography, prostitution and all kinds of 'deviation' were combated, with homosexuality at the forefront, while a model of culture that for many embodied sexuality and perversity was advocated." ${ }^{13}$ The interplay here was between authentic and innocent nudity on the one hand, and the perverse, "degenerate" variety visible especially in film and photography. The Security Service and SS were appalled "by educational films, claiming that such pictures »arouse a proclivity for sexual sensations much more than giving the objective information desirable from the point of view of the nationalbiological ideas of National Socialism«."14

\section{Masculinity as a Task}

The passage from Rodan's Last Days of Sodom quoted above portrays masculinity as a task or challenge. The dialogue of the lovers (Adolf and Eva) finishes with Hitler's words: "I'll soon take upon my shoulders a load exceeding the strength of a normal person!!"15 In Nazism, masculinity is elaborated, forged, but also hardened. In the work of Franco La Cecla, brusqueness is one of the

11 Antoni Sobański, Cywil w Berlinie, ed. Tomasz Szarota (Warszawa: Sic!, 2006), 36.

12 See the entry on "Nudism" in Rose Sala Rosa, Diccionario crítico de mitos y símbolos del nazismo [A Critical Dictionary of Nazi Myths and Symbols] (Barcelona: El Acantilado, 2003). Lech M. Nijakowski, Pornografia. Historia, znaczenie, gatunki (Warszawa: Iskry, 2010), 212.

14 Stefan Maiwald, Gerd Mischler, Seksualność w cieniu swastyki, trans. Ryszard Wojnakowski (Warszawa: Trio, 2003), 82. Original version Sexualität unter dem Hakenkreuz (Hamburg: Europa Verlag, 1999).

15 Rodan, Ostatnie dni Sodomy, 148. 
forms in which masculinity is disclosed and manifested, and masculinity itself is presented as a certain ideal state which can, but need not, be realised. ${ }^{16}$ Since this is the case, this means that it can be deformed, distorted. This is a genuine fear that never left the fascist eminences and ideologists responsible for the "health of the nation." From the outset, appropriate spiritual formation of the citizens of the Third Reich was the object of concern of the new educational system. Obedience and discipline were the foundations on which the young generation grew up. The severity of the Protestant and bourgeois upbringing came into contact with nationalist elements, and both areas were appropriated by technocratic procedures in the educational field. Their crowning glory was the Hitler Youth organisation. Hitlerjugend was created in the spirit of a devout relationship with sport, physical fitness and leadership, perceived against a background of biological and social Darwinism. These were supplemented by nationalism and the nationalistic songs intoned at Hitler Youth rallies.

Apart from their union of political objectives, German and Japanese fascism were also connected by an ideological kinship. One may look at both regimes from the perspective proposed by Ruth Benedict, who says of the primary characteristics of Japanese culture:

Japan $[. .$.$] put her hopes of victory on a different basis from that prevalent$ in the United States. She would win, she cried, a victory of spirit over matter [author's emphasis].17

This primacy of spirit over matter finds justification in both German and Japanese culture. In both too (and extremely strongly in the latter), the spirit is associated with the male.

In nineteenth-century Romantic-era Germany, divided into duchies of various sizes, the cult of one Germanic spirit matured and grew anew, to be embodied in the unification policy of Otto von Bismarck. Yet it found its fullest expression in the Nazi conception of the leader, who became the personification of the will of the people with all its members. At least this was how Goebbels's propaganda saw it, with the chant of "Ein Volk, Ein Reich, Ein Führer." In his book The Germans, Norbert Elias finds the characteristics of German behaviour that cast aside any leniency for human weakness and saw signs of fragility in tolerating shortcomings. According to Elias, this

16 Franco La Cecla, Modi Bruschi, antropologia del maschio (Milano: Elèuthera, 2010).

17 Ruth Benedict, The Chrysanthemum and the Sword: Patterns of Japanese Culture (Boston: Houghton Mifflin, 2005), 22. 
rigorousness was a clear distinction between the Germans and the English, who "left room for deviations from the norm as well as for individual eccentricities."18

In fascism, "the ideology of »the spirit « was an eclectic conglomerate of Old German myths, medieval mysticism and their own mysteries of the cult of race and Nordic blood."19 Nazism's relationship with religion (including Christianity) is a complex topic. Yet it is beyond doubt that its leaders - especially Himmler - tried to dress up the ideas of the Herrenvolk in religiousmystic robes. The head of the SS also often compared his organisation to medieval knightly orders. Among others, it was the Jesuits, with their loyalty to the pope, strict rules shaping and honing the interiors of the members of the order, that inspired Himmler and his endeavours to found an SS Order of Knights based in their own Germanic castle. ${ }^{20}$ This was Wewelsburg, the venue of secret meetings of a tight circle of the Reichsführer's colleagues. At the castle, he was embodied in the figure of a grand master of the new order, which was also to include women - SS members' wives to be precise. A rarely mentioned fact is that the sweethearts of SS men were obliged to present their genealogical lineage from 1750 to prove that there had been no contamination of Nordic blood since that time. Himmler scrupulously tested the "pedigree of girls who were said to be pregnant by SS men before he would grant them the necessary permit to marry."21

\section{The Test of Masculinity}

Masculinity is hardened when put to the test. Fascism knew several ways of testing the body and spirit of the new power elite. Yet, from the Nazi perspective, all verifications of masculinity pale in comparison to the fundamental test of the "community of atrocities." In his monumental treatise, Raul Hilberg writes of the "blood kit"22 - one founded on murder. The American historian refers to the words of Hans Frank, uttered in 1942 to representatives of Hitler's police:

18 Norbert Elias, "The Breakdown of Civilization," in The Germans, trans. Eric Dunning and Stephen Mennell (New York: Columbia University Press, 1996), 324.

19 Karol Grünberg, SS - czarna gwardia Hitlera (Warszawa: Książka i Wiedza, 1975), 115.

20 Roger Manvell and Heinrich Fraenkel, Heinrich Himmler: The Sinister Life of the Head of the SS and Gestapo (New York: Skyhorse, 2007), 48-49.

21 Ibid., 90.

22 Raul Hilberg, The Destruction of the European Jews, Volume III (New Haven-London: Yale University Press, 2003), 1080. 
We want to remember that we are, all of us assembled here, on Mr. Roosevelt's war criminals list. I have the honor of occupying first place on that list. We are therefore, so to speak, accomplices in a world-historical sense. $^{23}$

This "community of blood" is revealed even better by Himmler's speech to high-ranking SS officers and police given in Poznań in 1943. In it, the SS Reichsführer highlighted the category of being a chosen one in atrocities. This is clear proof that he was profoundly aware of what he was doing, and of exactly how much of a "tough task" awaited his subordinates. He knew that only "the best" could meet this challenge. The fact that this was the mission of men was as obvious an assumption as the fact that they had to come from SS ranks. Committing heinous crimes was something that separated the "masculine" from the "feminine." The man was a warrior, the torch of civilisation, lighting the way to contemporary and future generations. Murder also differentiated boyhood and maturity, which - as in mafia structures - was reached when one made a kill. It stratified the masculine and the unmasculine, that is feminine. Committing atrocities in Nazism was reserved for men not because women were psychologically incapable of it, but because their vocation was something low, less meaningful, superficial. After all, genocide was the road to a better world, to be paved by the most illustrious men, "martyrs for the cause."

Using various means to make murder a part of everyday experience, and thus psychologically familiar, fascism took care to preserve its "masculine" aspect. Hitler's 1939 order concerning Aktion T4, a prelude to the actual process of extermination of the Jews, left it up to doctors to put mentally ill patients to death. ${ }^{\mathbf{2 4}}$ The Nazi doctors did this on the ramp and at the camp hospital. The "angels of death" were therefore almost always men. The crime demanded obstinacy, "courage," resistance to the victims' crying and wailing - predispositions usually attributed to men. And yet, in the minds of some SS men, murder of the civilian population must have seemed to be something unmanly, "worse" than fighting on the front. Without diminishing the power of Himmler's propaganda, it is hard to believe that it always succeeded in overruling the cultural message which precluded thinking about killing women and children in terms of heroism. This dissonance must have been easier to discern in Wehrmacht units, which did not undergo thorough Nazi indoctrination. Some concentration camp officers understood this. As they were

23 Ibid.

24 Kathrin Kompisch, Sprawczynie, trans. Sławomir Kupisz, Natalia Badiyan-Siekierzycka (Warszawa: Prószyński Media, 2012), 199. Original version: Täterinnen: Frauen im Nazionalsozialismus (Köln: Böhlau Verlag), 2008. 
unable to demonstrate their courage and leadership skills on the battlefield, they used various means to maintain their authority among lower-ranking soldiers. The Prussian discipline of the drill and immaculate attire were meant to replace the authority, obedience and respect that in other conditions would be assured by the front. ${ }^{25}$

Yet the camps and extermination centres were not entirely excluded from the "field of glory." Apart from a sense of mission (strengthened in the SS crew), something existed that was not only a substitute for an officer's authority, but even exceeded it. The camp made its executioners almost unlimited lords of life and death, contemporary embodiments of medieval monarchs. Ernst Klee's description of Josef Mengele, that "to the end of his life he remained a biologist and a racist," ${ }^{26}$ is no doubt true. But this is only part of the truth about Nazi doctors. Auschwitz, Buchenwald, Ravensbrück, and Majdanek gave an ersatz sense of divinity, aroused by the awareness of the total dependence of others on their decisions.

The monstrosities of the Nazi era beg the question of whether there exist a "masculine" and a "feminine" style of crime. Can we justly speak of cruelty typical of women or men? What might distinguish each of these variants? I do not know of any scientific works that examine this issue closely. Two questions are beyond dispute: women and violence denote the need to break cultural stereotypes. Femininity is not easily associated with brutality and the realm of death. Rather, it is linked to life and procreation, not only in mythology and art, but in the popular consciousness as well.

In many situations - the camp being the paradigmatic example - women tried to imitate male cruelty and to match men in this respect. Documents and memoirs show that female wardens at Auschwitz and Majdanek, initially uncertain in their new roles, gradually took the initiative, modelling themselves on the behaviours of SS men and guards. At times, some of them - such as Irma Grese, Ilse Koch, Alice Orlowski, Maria Mandl, and Herta Oberheuser - eclipsed even male SS members with their barbarity.

In spite of their enthusiasm and fervour, nowadays overlooked, the female members of the camp staff or Wehrmacht auxiliary workers were not treated as full-fledged soldiers. ${ }^{27}$ In the army and camp hierarchy, they were relegated

25 Życie prywatne esesmanów w Auschwitz, ed. Piotr Setkiewicz, (Oświęcim: Państwowe Muzeum Auschwitz-Birkenau, 2012), 7.

26 Ernst Klee, Auschwitz. Medycyna III Rzeszy i jej ofiary, trans. Elżbieta Kalinowska-Styczeń (Kraków: Universitas, 2009), 442. Original version: Auschwitz, die NS-Medizin und ihre Opfer (Frankfurt: Fischer Taschenbuch, 2001).

27 This was the case even though they swore the same oath of fealty to Hitler, and were bound by the same penal code (Kompisch, Sprawczynie, 321). 
to a lower level. Women served mainly as clerical assistants and nurses. They never fought on the front, and did not participate in military actions. The decision to train women in the use of firearms was made very late in the Third Reich, in 1945, but even then, female battalions were not formed for fighting against enemy divisions. They therefore did "typical women's jobs" in the Wehrmacht. For some, service was tied to the hope of raising their social status and earning respect among male civilians, as well as having a chance to act upon their patriotic feelings.

Notwithstanding its unequivocally patriarchal approach to the world, Nazism created good conditions for the development of young, ambitious girls, especially those who were members of the NSDAP and SS. Hitler's ideology sometimes even manifested an emancipatory aspect in regard to women. Advocates of the modernity of Nazism could find arguments here. The model wives of SS men were supposed to have not only a suitable pedigree, but also similarly appropriate skills. According to Himmler's ideas, the right girl for an SS man ought to have a good knowledge of history, "know foreign languages and be able to ride a horse, swim, drive a car, shoot a pistol." ${ }^{28}$ These were rather progressive expectations, often far from the ideas of the time (even if we remember that the future wives of Himmler's elite were also expected to cook well and to know how to keep a household). Yet this does not change the fact that women were treated in an objective, patronising fashion, from a position of power. They were usually perceived in relation - in a subordinate, obliging relationship - to men. According to Himmler's designs, it was up to the SS and NSDAP's management to enable the men's separation from their wives if the latter did not live up to the ideal. He and Hitler planned to legalise bigamy, thus increasing the number of births. Bigamy was also meant to release internal competition, meaning that "every wife would become a stimulus for the other - all would try to be their husband's dream woman." ${ }^{29}$ Not for the first time in German fascism did modernity come into contact with conservatism.

\section{The Göttingen Architect}

In 1974 in his Spandau prison, commenting on a note made by Albert Speer, Joachim Fest writes that:

He says that he will never solve the mystery of his life. It's true that he was guilty, was branded a criminal, sentenced and so on. But what was

Grünberg, SS - czarna gwardia Hitlera, 107 
the alternative in terms of his life as a whole? Should he have preferred to spend the autumn of his life as a town planning advisor in Göttingen, looking back as an architect at the buildings of the municipal savings bank or the local swimming pool?30

If we are to look at Nazism from the perspective of revolutionary social transformation - as has often been done - it proves to be attractive also for reasons of ambition, the promise of prestige, the chance for changing one's professional status. ${ }^{31}$ Speer would have remained nothing more than a humble town planning advisor in Göttingen if Hitler had not noticed him and made him his chief architect.

In 1930 s Germany, the man was the head of a family, and upon him lay the responsibility for its financial upkeep. For the representatives of the lower social classes who staffed the ranks of the various police units (including the Gestapo), as well as SS and NSDAP members employed in civil administration, working for the regime guaranteed rapid promotion. Watching their colleagues - often life's losers or people of average intelligence and low resourcefulness - gradually climb the ladder of power and recognition, their peers no doubt felt an irresistible need to join them. Were they worse? Pragmatism and mercantilism not only made them feel no worse, but allowed them to shed their fears that they were maladjusted people, not understanding the winds of history. In his reportages from Nazi Germany published in the mid-1930s in Wiadomości Literackie, Antoni Sobański reaches the same conclusions, describing the lower social reaches and citing the irresistible desire for power - so close to human nature, regardless of social status:

So it is hardly surprising that the nervously and physically emaciated unemployed man, who until recently was perhaps even begging, and today suddenly has the chance to give orders, and to be feared by every civilian, is unable to resist the temptation..$^{32}$

30 Joachim Fest, Albert Speer: Conversations with Hitler's Architect, trans. Patrick Camiller (Cambridge: Polity Press, 2007), 165.

31 Speer's biographer writes the following about him: "Those who knew him well all pointed to the burning ambition beneath his restrained exterior; they thought that his matterof-factness was just a mask concealing his boundless and rarely challenged egotism." Joachim Fest, Speer: The Final Verdict, trans. Ewald Osers and Alexandra Dring (New York: Harcourt, 2001), 42. 
Joining the ranks supporting Hitler's civilizational revolution satisfied the bourgeois need to be useful. ${ }^{33}$ An SA or SS member was no longer standing on the sidelines; he was engaged and involved. His belief in his own worth and the correctness of his decisions must also have been affirmed by the awareness that he was working on behalf of the people. As if this were not enough, he sensed the enthusiasm that gripped Germany under the Führer's rule.

Leaving aside - but not ignoring - financial concerns, Nazism promised something equally alluring for the male section of society - adventure. This was a particularly attractive promise for eighteen-, nineteen- and twentyyear-olds, if only because it offered an excellent fulfilment of their youthful pursuit of the unknown, represented a test of independence, and an initiation into adult life. In many of these biographies, it is hard to ignore the context of the conservative environment of family homes. From the perspective of the tight-fitting chains of bourgeois morality, Nazism appeared as a visible sign of freedom for them, a substitute for another world, in which boyish and youthful bravura had the chance to be fulfilled. Those belonging to this age group happily jeopardize their lives, but are also prone to make ultimate declarative judgements; this was a perfect match for the revolutionary spirit of fascism. Speer's assertion therefore comes as no surprise: that in youth one cannot choose between what is known and ordered and what is different and mysterious, even if it is at the same time uncertain. It is only an apparent choice whose result is known from the start. Especially for people, like Speer, whose "early years followed the pattern of a regulated and uneventful youth in the provinces." 34

\section{The Domination of Men}

Himmler regarded the domination of men in the National Socialist state as self-evident and natural. As Pierre Bourdieu writes, in a patriarchal order, "the androcentric vision imposes itself as neutral and has no need to spell itself out in discourses aimed at legitimating it." 35 It explains the central position of the warrior as conqueror and at the same time defender of borders. This was

I use the word "revolution" here in the sense proposed by Hermann Rauschning, The Revolution of Nihilism: Warning to the West, trans. E. W. Dickes (Whitefish MT: Kessinger Publishing, 2005). 
what entitled him to occupy a unique position in the gender hierarchy, which also imitated the social hierarchy.

The privileged position of men in the Third Reich is manifest in the approach to extramarital relations. Engaging in such relations by soldiers on the front or units stationed in occupied territories was accepted in the belief that it was a boon to their vigour and battle fitness. Infidelity among wives in the Third Reich was condemned, on the other hand. In the eyes of Nazi ideologues, such behaviour on the part of women was a blow to the family. Sexual activity (particularly among married women) not serving procreation was viewed as unacceptable, as it threatened the National Socialist idea of the purity and modesty of the Aryan woman. ${ }^{36}$ Leaving aside the "concern" for the morals of German young ladies and mothers, the different treatment of the two sexes in Nazism resulted from a number of intertwined stereotypical ideas on the sexuality of women and men. The former should be passive, while to the latter was attributed activeness, freedom, and the associated licentiousness. By its very nature, male sexuality was viewed as the negation of the fidelity, obligation, and family stabilisation that characterised the female sex.

The Third Reich is an excellent example on which to analyse the structure of a system making symbolic violence a pillar of the state. Biological difference translates into the division of social roles. The woman's body and man's body become state property, answering to different rules and laws. The authorities usurp the right to control female (and male) sexuality. They define sexual partners ("Aryans"), but also the purpose of sexual activity ("procreation"). Himmler treated this supervision extremely seriously, his foresight in this respect reaching inquisitorial fervour:

In April 1942 Himmler signed an order exhorting his men not to seduce girls out of frivolity and so deprive the nation of potentially fruitful mothers. ${ }^{37}$

The wives of SS men who gave birth to seven or more children received the Mother's Cross of Honour.

Members of the SS had a unique role to play as the nation's racial and spiritual elite. Their leader took every opportunity to underline the organisation's privileged place in the structure of the new society (the Herrenvolk). Fascinated with Teutonic mythology, he searched within it for justifications for his ideas.

See Kompisch, Sprawczynie, 70-71. 
He also found them reading the texts of Guido von List, follower of Wotanism and devotee of the religions of the forefathers. ${ }^{\mathbf{3 8}}$

Following the model of the great Germanic heroes, the fascist does not die like an ordinary soldier, but "falls on the battlefield, gives his life, gives himself, offers himself as a sacrifice to ideals." 39 In this way, his body, as Jonathan Littell writes in Le sec et l'humide, is never tainted or desecrated, as it was elevated by a monumental idea. This is what protects from bodily and spiritual defilement. In Imagined Communities, Benedict Anderson notes that: "The idea of the ultimate sacrifice comes only with an idea of purity [...]."40

The ultimate idea required the ultimate sacrifice. And this could be attested only by death -heroic death. In Nazism, this acquired the form and significance of a founding myth. Under Goebbels's watchful eye, Nazi cinematography - apart from its anti-Semitic features - also had distinct heroic motifs. Dying soldiers and brothers in arms (like "Saint" Horst Wessel of the SA) affirmed the conviction of men as the chosen ones in courage, thus legitimising the political slogans of Nazism. The propaganda of the 1930 s was saturated in a religious, pious, quasi-mystic atmosphere. Young SA and SS men as well as members and sympathisers of the NSDAP were viewed as a contemporary embodiment of medieval saints, and the plots of films from the time took the form of hagiographic stories. As in the Middle Ages, it was not the individual, but the supra-individual dimension that counted in the death of a distinguished person (a hero). The deaths of warrior-martyrs found meaning in the victorious march towards control, and finally when the fascists came to power. ${ }^{41}$ The blood of martyrs consolidated society, strengthening it, and confirming the path chosen.

The pathos of Goebbels's cinematography leant inexorably towards kitsch - the caricatured masculinity known from macho culture. The film chronicles highlighted the athletic figures of young men, carrying the potential for aesthetic gaudiness generally favoured by all kinds of exaggerations and

38 See Nicholas Goodrick-Clarke, The Occult Roots of Nazism: The Ariosophists of Austria and Germany, 1890-1935 (Wellingborough: Aquarian Press, 1985).

39 Jonathan Littell, Suche i wilgotne. Krótka wyprawa na terytorium faszysty, trans. Magdalena Kamińska-Maurugeon (Kraków: Wydawnictwo Literackie, 2009), 55. Original version: Le sec et l'humide: Une brève incursion en territoire fasciste (Paris: Gallimard, 2008).

40 Benedict Anderson, Imagined Communities: Reflections on the Origin and Spread of $\mathrm{Na}$ tionalism (London-New York: Verso, 2006), 148.

41 See Piotr Zwierzchowski, "Śmierć założycielska. Pamięć, tożsamość, propaganda," in Spektakl i ideologia. Szkice o filmowych wyobrażeniach śmierci heroicznej (Kraków: Rabid, 2006), 95-134. 
monumentalisations. The personification of machismo came in the form of the Führer. Hitler, who was far removed from the ideal of the Aryan man, was portrayed as a capturer of women's hearts: rather on account of his rhetorical and technocratic abilities than his physique and external appearance. What German women, but German men too, loved in him was the notion of the strong leader, a man capable of drawing crowds. For women, he was the emanation of the characteristics that they looked for in the objects of their affection; for men, he was the embodiment of the conqueror that they wished to see in themselves. Like any love, this one too was realised in unlimited devotion to the object of desire. At least two manifestations of this devout veneration smack of cheap sentimentalism. First, there were the letters from German women which swamped the Führer, in which wives and maidens professed their love and readiness to bear children for the best son of the nation. Hitler sustained this erotic game. He remained a bachelor, speaking of his marriage to the Reich. He kept his romance with Eva Braun a secret. After all, the object of the dreams of so many could not be attached to one woman. Also infused with kitsch are the stories about Hitler's uniquely magnetic gaze. It is impossible to mention or list all the accounts which feature the motif of the Führer's hypnotic look. Women and men were equally susceptible. Their reactions call to mind the experiences of the readers of eighteenth- and nineteenth-century romances - close to swooning and entirely defenceless against the ideal lover. In his novella Puste oczy (Empty Eyes), Jerzy Putrament shows the actual meaning of this gaze, behind which lurked death and destruction. ${ }^{42}$ For some experts on fascism, however, what for Putrament constitutes proof of the error made by "ordinary Germans" is not so obvious. These researchers, citing the traditions of German Romanticism, argue that Hitler was putting into practice the German desire to lose oneself and the almost erotic fascination with death.

The hypnotic trope has been the subject of numerous historical and psychological interpretations, whose authors grappled with the question of the "fatal attraction" of an entire nation. Unfortunately, for some citizens of the Third Reich, this way of explaining the support enjoyed by Hitler and his henchmen was used as a self-justification: beguiled and deceived by the Führer, we were unable to do anything. The world of the twentieth-century triumph of science and technology was thereby derailed from the tracks of rationality and progress, embarking on a path previously marked by the tracks of divine veneration afforded to great tribal leaders.

Fascism sanctified male aggression. First, it extracted it from the mundane. In this sense, the often cited comparison of Nazism to a criminal organisation

42 Jerzy Putrament, "Puste oczy," in Wybór opowiadań (Warszawa: Czytelnik, 1975). 
(gang) is misplaced - however true it is in the ethical sense or in appraising the ways in which the two institutions have operated. Atrocity in Nazism served the national cause, and even a universal human mission. It was not "ordinary killing" or torture, but the emancipation of the will of the Führer, and thus of the whole of society. The paroxysm of evil also referred to the realm of myth that the Third Reich cited with relish. Therefore, SS men grew to the status of Germanic heroes, ready to sacrifice their life for the Fatherland and without pity for their enemies.

Analogies with the Teutonic forebears were revised with allusions to their austere customs and ascetic way of life. These were meant to express their supremacy and the specialness of the Germanic spirit - that from a thousand years before and during Hitler's own times. Jürgen Stroop refers to the unique cult in which he grew up, which in his homeland venerated Hermann (Arminius), the great chieftain of the Cherusci tribe..$^{43}$

At this point, we need to deal with the stereotype of "women's nature." Feminist circles often repeat the idea that violence is a male attribute. They are guided by certain findings of contemporary biology, especially from the field of so-called behavioural biology, which highlights that almost throughout nature, and particularly among anthropoid apes and in the Homo sapiens species, the quintessence of male specimens is manifested in violence. ${ }^{44} \mathrm{In}$ Täterinnen ("Perpetratresses"), Kathrin Kompisch takes issue with the position of contemporary feminists. Their tacit acceptance of the assumption of women's passive role in Nazism came with an equally consistent post-war silence around the crimes committed in concentration camps by female SS members. Only a small percentage of them were sentenced for these crimes. In 1950 s and '6os Germany, a debate took place over the atrocities and guilt of men. Notably, the opposition movement that culminated in the 1968 student revolt did not ask where "our mothers" were in the Third Reich era, but only "our fathers." 45 No doubt one of the reasons for this was the culturally entrenched conviction about the mild nature of women. At various levels, though, women were involved in supporting the regime. There is no evidence for the widespread view that "in 1933-1945 women mostly occupied the roles

43 Kazimierz Moczarski, Conversations with an Executioner (Upper Saddle River, N): PrenticeHall, 1981), 17. Arminius was a Germanic chieftain and hero of the Battle of the Teutoburg Forest, at which Germanic tribes destroyed Roman legions and ultimately halted their march onto Germanic territory. Violence (New York: Houghton Mifflin Harcourt, 1996). 
of housewives." 46 They worked at many levels of the Nazi terror machine: as secretaries in SS and Gestapo stations and posts, office workers preparing reports on mass executions, staff on the euthanasia programme, doctors conducting experiments on humans, and concentration camp wardens. Kompisch analyses various forms of women's participation in the functioning of the machinery of crime, opposing the widespread idea that they were merely passive victims. ${ }^{47}$

The perpetratresses also included the wives of SS men. [...] as supporters at the sides of their husbands, they reinvigorated their spirits and consolidated the criminal industry that they conducted in concentration camps and groupings. They took care of the family atmosphere at home, provided respite and diverted their husbands' attention from their everyday tasks, managed the household, endeavoured to make sure that the day passed without undue concerns and frictions, while raising the children in the spirit of National Socialism - in short, they took everyday hardships on their shoulders, taking the burden away from their husbands..$^{48}$

Apart from those direct "perpetratresses," who humiliated, beat, and murdered, we also encounter those whose perpetration entailed ideological support and justification (camouflage) of the murders of the Third Reich. ${ }^{49}$ These were the majority.

\section{The Humiliated Man}

This image is a common one in the works of various authors. It is presented in poetry and prose as well as memoirs. Let us reconstruct it in the words of Nechama Tec, a young Jewish girl for whom the failure of Hitler's Reich meant winning life:

If it had not been for those raised hands and his uniform, I would never have guessed that he was a German. His shoulders were stooped, his head was as low as his position allowed it to be, and he walked carefully, as if

46 lbid., 15.

47 See ibid., 350: "Women committed less criminal acts than men, because they were not engaged to commit crimes on such a scale, and not because they opposed or resisted the Nazi state."

48 Ibid., 303.

49 See ibid., 9-26. 
shaking with fear. Until then all the Nazis walked stiffly erect, with a sure gait and an arrogant expression on their faces, as if the whole world belonged to them. But this first Nazi I saw surrender looked like a broken man, devoid of all energy and spirit, an image of total submission.50

The recent victor - humiliated in his own eyes and in those of the ultimate victors - is a common sight, well known from the history of wars. In Tec's description, however, it is more than the vision of an indomitable army that lay in ruins. This semantic surplus is illustrated well by the phrase "like a broken man." The complement to German nationalism, extended to the limits of possibility, came in the form of the aggressive racist ideology of the Herrenvolk. The fascist warrior, beaten by the Soviet mercenary and the Allied Yankee, bowed to both systems, which proclaimed the idea of equality (leaving aside for the moment the practical and actual nature of Stalinist communism). In the mind of the German soldier, both symbolised a world of hostile values, and questioned the principle of "natural," biological inequality between people as the foundations of future society. This aspect of the Third Reich - the old dispute between those who cite the modernist attachment of Hitler's state and the opponents of this idea - clearly brings anti-modernist themes to the surface.

We can only truly comprehend the scale of the fall and size of the failure experienced by the German conqueror if we appreciate the place on the ladder of being from which he was toppled. Among the numerous explanations given by the sociologist and psychoanalyst Stephan Marks in response to the titular question of his book, "Why did they follow Hitler?," is the narcissistic dimension of fascism. The Third Reich is an excellent example of "collective narcissistic collusion," in which the devotion to the leader (the Führer) assumed and fulfilled the need to be admired. ${ }^{\mathbf{5 1}}$ The Nazis, but also the ordinary citizens of the Third Reich, felt (especially in the times of military triumph on the Western Front) unity with their leader and his politics. After all, military and political successes lay behind it, and above all, pride that was once lost returned, buoyed by the ideas of being the chosen race and people.

Although Polish literature is seldom willing to embrace this topic, the invaders sometimes aroused admiration, and even delight. The marvellously armed and stylishly dressed German officers no doubt embarrassed

50 Nechama Tec, Dry Tears: The Story of a Lost Childhood (New York: Oxford University Press, 1984), 211-212.

51 See Stephan Marks, Warum folgten sie Hitler? - Die Psychologie des Nationalsozialismus (Düsseldorf: Patmos Verlag, 2014), 107. 
certain Polish military men, as well as the civilian population. Bitterness was mixed with jealously, and anger with a suspicion of their own civilisational backwardness. In the accounts of peasants, one could often hear acclaim for the bearing of the German soldiers moving with the front, and even for the military police patrolling Polish villages. Against this background, a common mantra was the sight of Russian soldiers - badly equipped, terribly uniformed, more reminiscent of a band of criminals than a regular army.

The German officers - with cash to spend, well dressed, elegant, but also inspiring obedience - must have impressed some Polish women. This is a difficult subject, usually regarded as concerning women of easy virtue or the irresponsible flirts whose heads were shaved by the independence underground as punishment for sexual contacts with the enemy. And yet such relationships took place. In how many of them was the nimbus of the a significant factor? It is hard to determine this today - and no research has been done in this area. Perhaps detailed archive research combined with analysis of memoirs and fiction would give us a better indication. We can find something of the fascination with the invader in Ignacy Karpowicz's Sońka.

\section{Nazism and Homosexuality}

I am borrowing the title of this section from the writings of Stefania Zahorska. Reading her essays - and with the time when they were written in mind one is struck by the insight and originality of Zahorska's observations. In her reportages (Listy $z$ Niemiec [Letters from Germany]), published, like Sobański's texts, in the mid-1930s, she tries to probe the masculinity of fascism. She finds a strong connection with homosexuality, referring to the relatively common sexual relationships between men in SA circles. ${ }^{\mathbf{5 2}}$ Zahorska notes that this is part of the culture of warriors in which - let us add - the strong emotional bond between soldiers, incited by the bond of blood spilled in battle as well as group solidarity fuelled by the existence of a common enemy, lead to acceptance of homosexuality as a unique - perhaps the ultimate - form of closeness between men. This results in a phenomenon discussed by Eve Kosofsky Sedgwick - the "homosocial bond." 53 The sexual aspect here is secondary to emotional ties. In this way, groups of SA men expressed their contempt for the

52 Stefania Zahorska, "Listy z Niemiec. W szkole kadetów i panów," in Wybór pism. Reportaże, publicystyka, eseje, ed. Anna Nasiłowska (Warszawa: Wydawnictwo IBL PAN, 2010$), 56$.

53 Eve Kosofsky Sedgwick, "Homosocial Desire," "Sexual Politics and Sexual Meaning," in Between Men: English Literature and Male Homosocial Desire (New York: Columbia University Press, 1985), 1-10. 
old world. This was how Rauschning's "revolution of nihilism"54 was played out, in which "promiscuity" did not serve its own ends, but demonstrated the need to create a new morality; the old, ossified bourgeois ethics were to yield to the laws established by the cult of male strength. Ten years later, in 1944 on the pages of Dziennik Polski, Zahorska's comments on Peter Nathan's book The Psychology of Fascism ${ }^{55}$ referred to the movement as absolutising and deifying masculinity. National Socialism came from:

[The] overestimation, idealisation of masculinity. [...] For this ideal of masculinity, unfettered in its force, brutality, savagery, calling upon everything and all to fight even without fear - is only a hypercompensation of the male, uncertain of his masculinity, profoundly fearful of his lack of strength. [...] From this fear emerges an aversion to women that assumes the form of contempt for her. Fear of one's weakness is projected outwardly as contempt for all weakness, as a cult of heroism. ${ }^{\mathbf{5 6}}$

This view of Nazism means searching for its sources in reaction to the emancipation of women, to their increasingly marked presence in Western culture. Of course, these are issues that go beyond the history of European fascism. Following the interpretation proposed by Nathan and Zahorska, one would need to see not only all military organisations, but also war itself, as peculiar enclaves of masculinity closed to women. The fact that war is a domain of gender, and not of human sexuality, can be best seen with the example of the roles played by German women on the front. As was also the case in the Allied armies, they were not permitted to engage in armed combat, but sent into support services (usually as nurses).

In the Third Reich - that which ensued after the murder of Ernst Röhm and part of the SA upper command - homosexuality was punishable, and homosexuals ended up in camps and prisons. But it was not breaking of moral imperatives (secularly motivated and religious-based) that aroused this reaction from the Nazis. Much worse than infringing "the laws of nature" in the case of homosexuality was the refusal to participate in the "community of masculinity." After all, people with different sexual orientation did not participate in the holy act of conception. Possessing progeny and the ability to perform defloration are a marker of masculinity, inextricably linked to manliness "in its ethical aspect: [...] the point of honour [...] the principle of the conservation

\footnotetext{
54 Rauschning, The Revolution of Nihilism.

55 Peter Nathan, The Psychology of Fascism (London: Faber and Faber, 1943).

56 Zahorska, "Psychologia faszyzmu," in Wybór pism, 255.
} 
and increase of honour."57 As Bourdieu shows, there is an association of "phallic erection with the vital dynamic of swelling which is immanent in the whole process of natural reproduction (germination, gestation, etc.)." ${ }^{88}$ The ability to sire children denotes an extension of male power, the emphatic expression of creation and construction of the world on androcentric principles. As Bernard Nuss writes:

The Germans were fascinated by Hitler, someone with a mediocre personality, but equipped with a remarkable desire for power and energy that could be regarded as absolute. The myth of strength plays an important role in German mentality. ${ }^{59}$

Strength as an attribute of masculinity seemed to correspond with, and to convey superbly, the desires and qualities of the entire nation. We observed the politically desirable apotheosis of everything habitually associated with the sphere of masculinity, and, equally habitually, treated as a negation of femininity.

Homosexuals were insinuated to be "soft," a weakness supposedly proven by their effeminacies. The fact that many homosexuals (including the leader) participated in brutal SA actions changes nothing. Homosexuals were relegated to being non-men, that is women and children. They were associated with decadence, debauchery, everything that in Western civilisation is at odds with vital energy.

\section{*⿻一}

In researching on Holocaust (and, more broadly, war) literature, there remains an area that still requires in-depth reflection. This is examining the Shoah from the perspective of the body - still ignored because of the idea of the subject without gender. As Paweł Wolski rightly asks,

how is it possible that a witness of the Holocaust is both a person endowed with a body and a bodily perspective, and all the while an unbiased, and thus bodiless, observer describing "bare facts"?60

57 Bourdieu, Masculine Domination, 12.

58 Ibid., 13.

59 Bernard Nuss, Syndrom Fausta. Próba opisania mentalności Niemców, trans. J. Karbowska (Warszawa: PIW, 1995), 69. Original version: Das Faust-Syndrom (Bonn: Bouvier, 1993).

60 Paweł Wolski, Tadeusz Borowski - Primo Levi. Prze-pisywanie literatury Holocaustu (Warszawa: Wydawnictwo IBL PAN, 2013), 278. 
The obscured corporeality of the witness is an important field of consideration on the Holocaust. ${ }^{61}$ In fact, texts concerning the concentration camp experiences camp seem especially inspired by the reflective perspective on corporeality. ${ }^{62}$ But whereas gender studies is gradually also embracing the Holocaust and war, ${ }^{63}$ in the Polish-language literature on the subject, it is men's studies that barely exists. ${ }^{64}$

Translation: Benjamin Koschalka

61 This has for some time been part of Paweł Wolski's academic research. See Wolski, "Boks w Auschwitz. Opór ciała," in Adlojada. Biografia i świadectwo, ed. Jaromir Brejdak, Dariusz Kacprzak, Jerzy Madejski, Beata Małgorzata Wolska (Warszawa: Muzeum Narodowe w Szczecinie, 2014).

62 Bożena Karwowska, Ciało, seksualność, obozy zagłady (Kraków: Universitas, 2009).

63 Aleksandra Ubertowska, "»Niewidzialne świadectwa«. Perspektywa feministyczna w badaniach nad literaturą Holokaustu," Teksty Drugie 4 (2009); Ubertowska, "Pisałam sercem i krwiq. Poetyka kobiecych świadectw holokaustowych," Ruch Literacki 6 (2008); Joanna Stöcker-Sobelman, Kobiety Holokaustu. Feministyczna perspektywa w badaniach nad Shoah. Kazus KL Auschwitz-Birkenau (Warszawa: Trio, 2012); Weronika Grzebalska, Płeć powstania warszawskiego (Warszawa: Wydawnictwo IBL PAN, 2013).

64 An exception is Tomasz Tomasik's Wojna - męskość - literatura (Słupsk: Wydawnictwo Naukowe Akademii Pomorskiej, 2013). 